\title{
Effect of Recreation on the Species Richness and Diversity of Rotifers in Ponds
}

\author{
Ewa Skowronek ${ }^{1}$, Anna Cudak ${ }^{1}$, Irena Bielańska-Grajner ${ }^{2}$ \\ ${ }^{1}$ Department of Ecology, University of Silesia, Katowice, Poland \\ ${ }^{2}$ Department of Hydrobiology, University of Silesia, Katowice, Poland \\ Email: anna_cudak@10g.pl, irena.bielanska-grajner@us.edu.pl
}

Received July 14, 2010; revised August 24, 2010; accepted September 20, 2010

\begin{abstract}
Planktonic rotifers were examined from April to October 2007 in two ponds created by sand extraction: Hubertus III (infrequently used for recreation) - pond I and Stawiki (commonly used for recreation) - pond II. The ponds are located within the protected Landscape Complex "Szopienice-Borki" in Silesian Upland (SW Poland). A total number of 58 taxa of rotifers were noted. The number of rotifer species and their densities were smaller in pond I than in pond II. In pond I, Polyarthra species were the most abundant, accounting for $48 \%$ of total rotifer density, whereas in pond II, Keratella cochlearis reached the highest density (accounting for $36 \%$ of total density). Analysis of variance (ANOVA) revealed a significant difference between communities of rotifers in species diversity $(F=5.88, p=0.02)$ and species richness $(\mathrm{F}=5.57, \mathrm{p}=0.03)$. The research proved that the pond commonly used for recreation (pond II) is characterized by a higher trophic state. Results of this study indicate that the methods and range of use of water bodies by humans have an important influence on the species richness and diversity of communities of planktonic rotifers.
\end{abstract}

Keywords: Indicators; Rotifers Community; Trophic Status

\section{Introduction}

There are many publications showing the usefulness of analyses of zooplankton structure and composition for trophic state assessment of water bodies [1-6]. Rotifers are the most important metazoans among the plankton because of their role as very good indicators of eutrophication [7-9].

However, there are few reports on the impact of human activity, including recreation, on zooplankton in water bodies used by people for this purpose [10].

In the Silesian Upland, many water bodies are artificial but characterized by a high environmental value. They are often attractive as sites for recreation and leisure, and are used for sailing, canoeing or kayaking, angling, powerboating, and leisure at natural and artificial recreational beaches [11].

This study was aimed to assess the influence of the recreational use of artificial water bodies on the basis of planktonic rotifer communities in ponds of the Natural Landscape Complex "Szopienice-Borki". Their rotifer communities have never been studied before.

\section{Methods}

Material was collected within the Natural Landscape Complex "Szopienice-Borki", from two ponds: Hubertus
III (I) and Stawiki (II). The area lies at the border of three cities: Katowice, Sosnowiec, and Mysłowice. With respect to geomorphology, the northern part of the study area lies in the Brynica Valley, the southwestern part in the Rawa Valley, and the southeastern part in the Mysłowice Valley. The ponds are surrounded by urban industrial areas, wastelands, arable fields in the northwestern part, woodlots, and recreational grounds of Sosnowiec. The study area is now highly valuable because of its landscape and environmental qualities.

All the ponds located in the study area were created as a result of sand extraction for concrete needed in the local coal mines. In the course of restoration, the large sandpits were flooded, and the resultant ponds cover a total area of about 101.5 hectares. The ponds are fed by the first level of groundwater and precipitation.

The ponds selected for this study differ in size, depth, and intensity and type of human impact (Table 1). The pond I is larger (ca. 20 ha), deeper (max. depth ca. 4 m), and rarely used for sports and recreation. The pond II (area ca. 7.5 ha and max. depth ca. $2.5 \mathrm{~m}$ ), managed by the Polish Lifeguard Association (WOPR), is characterized, first of all, by a large degree of human disturbance. Sailing shows, competitions, and races are organized there frequently. Moreover, the pond is regularly stocked with fish by the Polish Angling Association. 
Table 1. Combined limnological characteristics of the ponds included in this study.

\begin{tabular}{cccc}
\hline & Pond I & Pond II & ANOVA \\
\hline Surface area $(\mathrm{ha})$ & 20 & 7.5 & - \\
Maximum depth $(\mathrm{m})$ & 4 & 2.5 & - \\
Temperature $\left({ }^{\circ} \mathrm{C}\right)$ & $18.11 \pm 6.68$ & $18.19 \pm 7.54$ & $\mathrm{~F}=0.002 \mathrm{p}=0.966$ \\
Dissolved oxygen $\left(\mathrm{mgO}_{2} \cdot \mathrm{dm}^{-3}\right)$ & $8.63 \pm 1.13$ & $9.39 \pm 1.29$ & $\mathrm{~F}=5.519 \mathrm{p}=0.022$ \\
$\mathrm{pH}$ & $7.87 \pm 0.70$ & $7.81 \pm 0.76$ & $\mathrm{~F}=0.054 \mathrm{p}=0.817$ \\
Conductivity $\left(\mu \mathrm{S} \cdot \mathrm{cm}^{-1}\right)$ & $422.86 \pm 49.83$ & $789.29 \pm 85.17$ & $\mathrm{~F}=193.059 \mathrm{p}=0.001$ \\
Dissolved solids $\left(\mathrm{mg} \cdot \mathrm{dm}^{-3}\right)$ & $217.14 \pm 36.88$ & $385.00 \pm 50.34$ & $\mathrm{~F}=101.273 \mathrm{p}=0.001$ \\
Nitrate $\left(\mathrm{mgNO}_{\mathrm{x}} \cdot \mathrm{dm}^{-3}\right)$ & $3.22 \pm 1.97$ & $3.49 \pm 2.71$ & $\mathrm{~F}=0.092 \mathrm{p}=0.764$ \\
Phosphate $\left(\mathrm{mgPO}_{4} \cdot \mathrm{dm}^{-3}\right)$ & $0.13 \pm 0.07$ & $0.23 \pm 0.32$ & $\mathrm{~F}=1.373 \mathrm{p}=0.252$ \\
\hline
\end{tabular}

Natural conditions in the ponds, as well as the degree of their human transformation, are reflected in differences in physicochemical properties of pond water. Physicochemical analysis of pond water detected significant differences in oxygen content $(\mathrm{F}=5.52, \mathrm{p}=0.02)$, as well as conductivity $(\mathrm{F}=193.06, \mathrm{p}=0.000)$ and total dissolved solids $(\mathrm{F}=101.27, \mathrm{p}=0.000)$. In pond $\mathrm{B}$, which is intensively used for recreation, conductivity and total dissolved solids were the much higher than in pond I (Table 1). Levels of nitrates and phosphates in both ponds were relatively low and in most cases fitted within the standard ranges defined in Poland for water purity classes 1 (drinking water) and 2 (slightly polluted).

Material for this study was collected from April to October 2007, every two weeks. Samples were collected at a distance of $2 \mathrm{~m}$ from the pond edge, in each pond from two sampling stations: one sample for qualitative and another for quantitative analysis. In total, 112 samples were analysed.

Qualitative samples were collected by triple casting a plankton net no. 25. The collected material was examined alive, and special attention was paid to illoricate rotifers, which are deformed after preservation. Quantitative samples were prepared by filtering $10 \mathrm{dm}^{-3}$ of water through a plankton net. Next the sample volume was reduced to $0.05 \mathrm{dm}^{-3}$, and preserved with a mixture of formalin, glycerol, and water (3:1:6). Individuals of each rotifer species were counted in 5 Kolkwitz chambers (1 $\mathrm{cm}^{-3}$ each).

When collecting the water samples for biological research, additional water samples were taken for analyses of physicochemical parameters: temperature, dissolved oxygen, $\mathrm{pH}$, conductivity, total dissolved solids, nitrates, and phosphates.

On the basis of the results, we assessed species richness, abundance, and Shannon index of species diversity for rotifer communities. One-way ANOVA was used for statistical analysis of differences between the diversity and species richness of rotifers in ponds as well as between individual physicochemical parameters of water.
The analyses were made by STATISTICA 7.0 software. In order to compare more precisely the species richness of their communities in ponds, rarefaction analysis was made with the use of zero models based on the Monte Carlo method. For this purpose, EcoSim software was used [12]. On the basis of the rotifer communities, we assessed the trophic state of the ponds. MVSP 3.1 software was used to perform principal component analysis (PCA), to show associations of various rotifer species to their habitats, and canonical correspondence analysis (CCA), to show relations between individual rotifer taxa and abiotic factors. All species were taken into account in these analyses, but their results were not interpreted for the least frequent species, whose contribution to the total catch did not exceed 4\% (for PCA) or 1\% (for CCA). Additionally, in CCA, the option of down weighting rare species was employed.

\section{Results}

In total, 58 rotifer taxa were recorded in the studied ponds. Species richness was slightly higher in pond II, which is intensively used for recreation, as 48 species and forms of rotifers were found there. In pond I, we found 41 rotifer taxa. Differences in species richness between the ponds during the study period were significant (ANOVA, F = 5.57, $\mathrm{p}=0.03$ ) (Table 2).

Results of this study also show large differences in rotifer abundance between the ponds (Figure 1, Table 2). In pond II, their mean abundance was 740 ind $\cdot \mathrm{dm}^{-3}$, while in pond I, only 476 ind $\cdot \mathrm{dm}^{3}$. The highest densities were reached, particularly in summer in pond II, by the eurytopic Keratella cochlearis, which accounted for $36 \%$ of the total catch. In contrast, Polyarthra species accounted for more than a half of rotifer individuals $(48 \%$ of the total catch) in pond I. During the study period, various species of this genus dominated: Polyarthra dolichoptera in spring and autumn, while $P$. vulgaris, $P$. major, and $P$. remata in summer. A substantial increase in abundance of Polyarthra species was observed in pond I 
Table 2. Ecological indicators of the studied rotifer communities.

\begin{tabular}{lccc}
\hline & Pond I & Pond II & ANOVA \\
\hline Medium density $\left(\right.$ ind $\left.\cdot \mathrm{dm}^{-3}\right)$ & 475.96 & 740.00 & - \\
Total density $\left(\right.$ ind $\left.\cdot \mathrm{dm}^{-3}\right)$ & 6664 & 10360 & $\mathrm{~F}=5.57, \mathrm{p}=0.03$ \\
Number of species & 41 & 48 & $\mathrm{~F}=5.88, \mathrm{p}=0.02$ \\
Shannon index & 1.126 & 1.475 & - \\
Indicators of trophic status & 4 & 27.43 & - \\
$\begin{array}{l}\text { Percentage contribution of "tecta" } \\
\text { in total population Keratella cochlearis [\%] }\end{array}$ & 8.11 & & \\
\hline
\end{tabular}

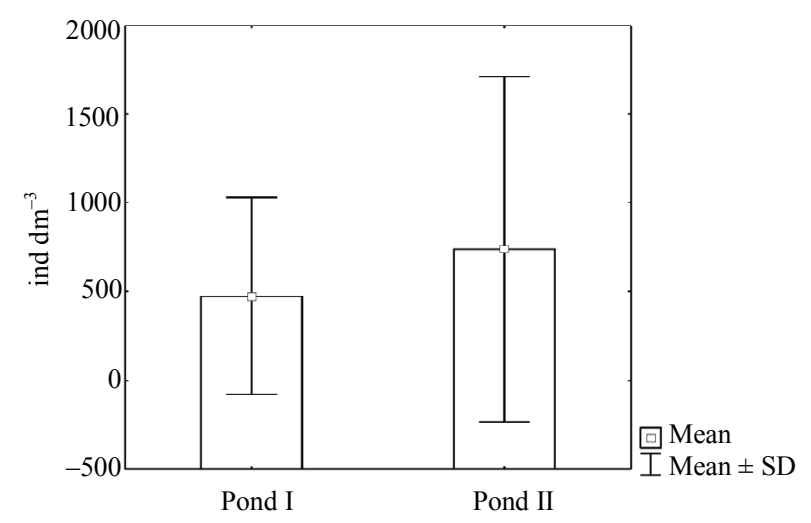

Figure 1. Mean density (April-October 2007) of rotifers in two ponds.

particularly in spring and early autumn. An abundance peak recorded in late summer in pond II was also due to mass appearance of Polyarthra species. Variation in species richness and abundance of rotifers in the studied ponds is shown by rarefaction curves of species richness. The curves indicate that species richness was much higher in pond B, irrespective of sample size (Figure 2). The collected data on abundance and species richness affected also the Shannon diversity index, which was higher in pond II (1.48) than in pond I (1.13) (Table 2). Considering the whole study period, the values of the Shannon diversity index differed significantly between the ponds (ANOVA, $F=5.88, p=0.02$ ). In the studied water bodies, we observed several species regarded by many researchers as indicators of high trophic state [13, 14]. In pond $A$, four indicator species were recorded: Brachionus angularis, Keratella cochlearis f.tecta, Keratella quadrata, Trichocerca similis. In pond B, apart from the above-mentioned taxa, seven other indicator species were found as well: Brachionus diversicornis, Brachionus falcatus, Brachionus quadridentatus, Filinia longiseta, Pompholyx sulcata, Trichocerca capucina, Trichocerca pusilla. All the species that dominated the rotifer communities in the studied ponds are characteristic of high trophic state. The much higher contribution of indicator species in pond II, suggests that this pond is more fertile. An analysis of other factors confirms these

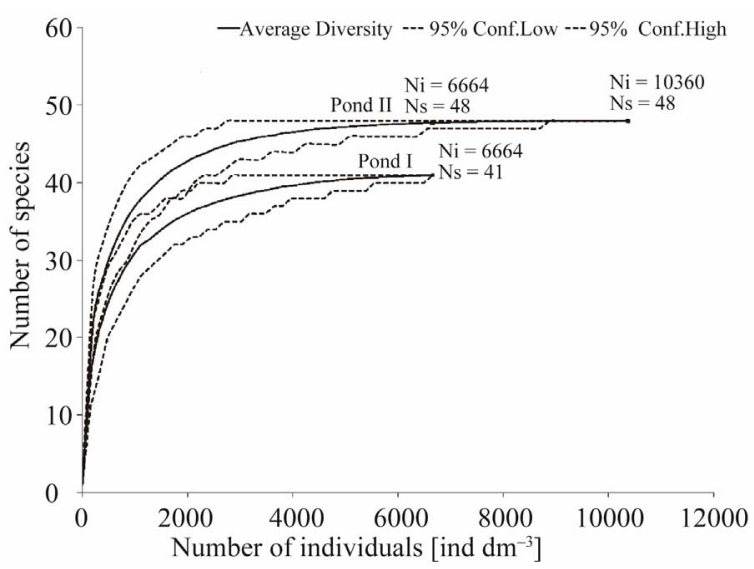

Figure 2. Species richness and species diversity reflected by the rarefaction curves.

results. The contribution of the tecta form to the total population size of Keratella cochlearis, which reached $13.4 \%$ in pond II and only $2.1 \%$ in pond I, indicates that the former is more fertile.

\section{Discussion}

In the studied ponds, the small number of rotifer species and planktonic forms is characteristic of anthropogenic water bodies in the Silesian Upland. In the studied ponds of the Natural Landscape Complex "Szopienice-Borki", a total of 58 rotifer taxa were identified. An even lower, species richness was recorded in other flooded mineral extraction sites. In Łysina, 52 taxa were recorded, while only 26 taxa in Sosina [15]. The dominant species in the studied ponds, e.g. Keratella cochlearis, Polyarthra sp., Kellicottia longispina, Trichocerca similis, and Synchaeta sp., are common rotifers, characterized by a wide distribution and low environmental requirements. Their dominant role was also reported from other flooded extraction sites in the Silesian Upland $[15,16]$. Particularly the eurytopic Keratella cochlearis is often a dominant in various water bodies, irrespective of the trophic state [13]. The species was abundant not only in anthropogenic water bodies in the Upper Silesia region but also in other waters of Poland and other European countries, e.g. in 
urban lakes in Poznań [17], Lake Łuknajno [3], and in extreme conditions, such as the strongly radioactively polluted river Pripyat (Prypiat) in the Chernobyl region [18], in the Grošnica Reservoir, Serbia [19].

The comparison of rotifer communities between lakes free from human activity, located in the Wielkopolska National Park, and urban recreational lakes near Poznań showed that in recreational lakes rotifer species diversity was lower, while abundance was higher [10]. In contrast, in the recreational pond $\mathrm{B}$, both species richness was higher and rotifer abundance was much greater. These disparities result from differences in the character of the water bodies, their genesis, degree of transformation, size, depth, and the catchment area.

An analysis of changes in rotifer density in the studied ponds revealed remarkable differences between pond I and pond II, where the density was nearly 2 -fold higher. However, in both ponds, rotifer abundance was comparable with that recorded in other flooded extraction sites in the Silesian Upland. Similar rotifer densities were found in the extraction sites Dziećkowice, Pławniowice Duże, and Sosina [15]. Much higher densities were observed in mining lakes, formed as a result of subsidence on the Silesian Upland, reaching up to 8500 ind $\cdot \mathrm{dm}^{-3}$ [20].

The intensity of recreational use of water bodies affects their water quality. In pond II, which is intensively used for recreation, more species characteristic of high trophic state were recorded and the contributions of the tecta form to the total rotifer community and to the total population of Keratella cochlearis were much higher. This suggests that pond II has been subject to eutrophication. According to the scale recommended by [3], pond II is mesoeutrophic while pond I is mesotrophic. The higher fertility of pond II is also confirmed by a much higher rotifer abundance than in pond I. This may be due to its regular stocking with fish.

Changes in aquatic ecosystems subjected to the pressure of human recreation and water sports are evidenced by physicochemical analyses of water in the studied ponds. This applies especially to an increased concentration of soluble substances, measured as conductivity and organic matter content. Results of analyses of those factors corresponded to changes in rotifer communities, which is reflected in strong correlations between the factors and rotifer abundance, species diversity and species richness. However, no significant differences were detected in levels of nitrates and phosphates, which contribute to eutrophication. A similar situation was observed by [7]. Remarkable differences and changes in the structure of planktonic rotifer communities attest to significant changes in trophic state of the water body that is intensively used for recreation. This confirms that biological analyses need to be made in the course of water quality assessment and when planning actions aimed at water quality improvement.

The studied ponds with a sandy bottom were characterized by a low trophic status and therefore its increase caused an increase in the density and biodiversity of rotifers. This contrasts with conclusions presented by the majority of authors, who have indicated that a very strong increase in trophic status in water bodies results in a decreased diversity and density of rotifer communities [21-23].

\section{Conclusion}

As a result of the research in two ponds of the Natural Landscape Complex "Szopienice-Borki", we observed some changes in the structure of planktonic rotifer communities in pond II, which is intensively used for recreation. An increase was noticed in rotifer density, species richness, and species diversity, combined with changes in species composition, which attested to gradual eutrophication of this water body.

\section{Acknowledgements}

We thank Sylwia Ufnalska M.Sc. for translating and revising our manuscript.

\section{REFERENCES}

[1] M. Casé, E. E. Leça, S. Neumann Leitão, E. E. Sant'Anna, R. Schwamborn and A. T. de Moraes Jr., "Plankton Community as an Indicator of Water Quality in Tropical Shrim Culture Ponds," Marine Pollution Bulletin, Vol. 56, No. 7, 2008, pp. 1343-1352.

doi:10.1016/j.marpolbul.2008.02.008

[2] I. C. Duggan, Green and K. Thomasson, "Do Rotifers Have Potential as Bioindicators of Lake Trophic State?" Verhandlungen des Internationalen Verein Limnologie, Vol. 27, 2001, pp. 3497-3502.

[3] A. Karabin, J. Ejsmont-Karabin and R. Kornatowska, "Eutrophication Processes in a Shallow, MacrophyteDominated Lake-Factors Influencing Zooplankton Structure an Density in Lake Łuknajno (Poland)," Hydrobiologia, Vol. 342-343, 1997, pp. 401-409. doi:10.1023/A:1017003810282

[4] N. D. Saksena, "Rotifera as Indicators of Water Quality," Acta Hydrochimica et Hydrobiologica, Vol. 15, No. 5, 1987, pp. 481-485. doi:10.1002/aheh.19870150507

[5] R. L. Whitman, M. B. Nevers, M. L. Goodrich, P. C. Murphy and B. C. Davis, "Characterization of Lake Michigan Coastal Lakes Using Zooplankton Assemblages," Ecological Indicators, Vol. 4, No. 4, 2004, pp. 277-286. doi:10.1016/j.ecolind.2004.08.001

[6] O. I. Vandysh, "Zooplankton as an Indicator of the State of Lake Ecosystems Polluted with Mining Wastewater in the Kola Peninsula," Russian Journal of Ecology, Vol. 35, No. 2, 2004, pp. 110-116. 


\section{doi:10.1023/B:RUSE.0000018936.56649.20}

[7] Z. Ferdous and A. K. M. Muktadir, "A Review: Potentiality of Zooplankton as Bioindicator," American Journal of Applied Sciences, Vol. 6, No. 10, 2009, pp. 1815-1819. doi:10.3844/ajassp.2009.1815.1819

[8] S. Lodi, L. C. G. Vieira, L. F. M. Velho, C. C. Bonecker, P. de Carvalho and L. M. Bini, "Zooplankton Community Metrics as Indicators of Eutrophication in Urban Lakes," Natureza \& Conservação, Vol. 9, No. 1, 2011, pp. 87-92. doi:10.4322/natcon.2011.011

[9] D. D. Kane, S. I. Gordon, M. Munawar, M. N. Charlton and D. A. Culver, "The Planktonic Index of Biotic Intergrity (P-IBI): An Approach for Assessing Lake Ecosystem Health," Ecological Indicators, Vol. 9, 2009, pp. 1234-1247. doi:10.1051/limn/1985017

[10] N. Kuczyńska-Kippen, P. Nowosad and G. Grzegorz, “Ocena Jakości Wód Jezior Wielkopolskiego Parku Narodowego Oraz Zbiorników Rekreacyjnych Miasta Poznania w Okresie Wiosennym," Roczniki Akademii Rolniczej w Poznaniu CCCLXIII, Vol. 7, 2004, pp. 193-200 (in English Summary).

[11] M. Rzętała, "Funkcjonowanie Zbiorników Wodnych oraz Przebieg Procesów Limnicznych w Warunkdach Zróżnicowanej Antropopresji na Przykładzie Regionu Górnośląskiego," 2008 (in English Summary).

[12] N. J. Gotelli and G. L. Entsminger, "EcoSim: Null Models Software for Ecology," Acquired Intelligence Inc. \& Kesey-Bear Jericho, VT 05465, 2006. http://garyentsminger.com/ecosim.htm

[13] L. K. Matveeva, "Can Pelagic Rotifers Be Used as Indicators of Lake Trophic State," Verhandlungen des Internationalen Verein Limnologie, Vol. 24, 1991, pp. 27612763.

[14] A. Karabin, "Pelagic Zooplankton (Rotatoria and Crustacea) Variation in the Process of Lake Eutrophication. 1. Structural and Quantitative Features," Ekologia Polska, Vol. 33, 1985, pp. 567-616.

[15] I. Bielańska-Grajner, A. Gładysz, B. Furman, A. Gadomska, A. Kopaczyńska-Nowacka and K. Żymełka,
"Rotifer Communities in Reservoirs Created by Sand Extraction in the Silesian Upland," Teka Komisji Ochrony $i$ Kształtowania Środowiska Przyrodniczego, Vol. 5, 2008, pp. 12-17.

[16] I. Bielańska-Grajner and B. Kłos, "Planktonie Rotifers (Rotatoria) in Two Fidel Ponds in Rudziniec (Upper Silesia)," Acta Biologica Silesiana, Vol. 36, 2002, pp. 105116.

[17] J. Ejsmont-Karabin and N. Kuczyńska-Kippen, "Urban Rotifers: Structure and Densities of Rotifer Communities in Water Dobies of the Poznań Agglomeration Area (Western Poland)," Hydrobiologia, Vol. 446-447, No. 1, 2001, pp. 165-171. doi:10.1023/A:1017555424078

[18] G. A. Galkovskaya and D. V. Molotkov, "Species Diversity and Dominance in the Planktonic Rotifer Community of the Pripyat River in the Chernobyl Region (19881996)," Hydrobiologia, Vol. 446-447, No. 1, 2001, pp. 179-185. doi:10.1023/A:1017559624987

[19] A. M. Ostojić, "Effect of Eutrophication on Changes in the Composition of Zooplankton in the Grośnica Reservoir (Serbia, Yugoslavia)". Hydrobiologia, Vol. 436, 2000, pp. 171-178. doi:10.1023/A:1026539616969

[20] I. Bielańska-Grajner and A. Gładysz, "Planktonic Rotifers in Mining Lakes in the Silesian Upland: Relationship to Environmental Parameters," Limnologica, Vol. 40, No. 1, 2010, pp. 67-72. doi:10.1016/j.limno.2009.05.003

[21] D. O. Hessen and J. P. Nilssen, "Factors Controlling Rotifer Abundances in a Norwegian Eutrophic Lake: An Experimental Study," Annales de Limnologie, Vol. 21, No. 2, 1985, pp. 97-105. doi:10.1051/limn/1985017

[22] B. B. Castro, S. C. Antunes, R. Pereira, A. M. V. M. Soares and F. Goncalves, "Rotifer Community Structure in Three Shallow Lakes: Seasonal Fluctuations and Explanatory Factors," Hydrobiologia, Vol. 543, No. 1, 2005, pp. 221-232. doi:10.1007/s10750-004-7453-8

[23] C. Baião and M. J. Boavida, "Rotifers of Portuguese Reservoirs in River Tejo Catchment: Relations with Trophic State," Limnetica, Vol. 24, No. 1-2, 2005, pp. 103-114. 